\title{
A MODEL FOR SIMULATING TRANSPIRATION OF LEAVES WITH SPECIAL ATTENTION TO STOMATAL FUNCTIONING
}

\author{
BY F. W. T. PENNING DE VRIES
}

Department of Theoretical Production Ecology, Agricultural University, Wageningen, The Netherlands

\section{INTRODUCTION}

The model presented, which we refer to as TRALF, is an attempt to simulate the transpiration rate of a non-growing leaf throughout a day under varying environmental conditions using time intervals in the order of $10 \mathrm{sec}$. Stomata play a key role in the control of the transpiration process. Therefore special attention is paid to stomatal properties and factors governing stomatal aperture namely, plant water status, $\mathrm{CO}_{2}$ concentration and light intensity. Endogenous rhythms of stomata and long term trends of stomatal osmotic potential are not considered.

The equations by which the energy and gaseous exchange from irradiated and evaporating wet surfaces may be calculated, are well known (Slatyer 1967). Using such equations and some widely accepted assumptions concerning cuticular and stomatal diffusive resistances, a static model of leaf transpiration may be built, from which the constant equilibrium leaf temperature and transpiration rate can be derived. In a dynamic model the continuously changing leaf water status and the time-dependent behaviour of stomata should be considered. In order to achieve this a balance of water lost and gained by the leaf and the root must be kept. The stomatal aperture, which determines stomatal resistance, is the resultant of the relative water content of the guard cells and surrounding epidermal cells. Both follow the relative leaf water content with a time lag. Due to the special shape of guard cell walls an increase in volume of guard cells causes the stomata to open and vice versa. Subsidiary cells, neighbouring cells of stomata, are quantitatively less important and are supposed to work in the opposite way (Meidner \& Mansfield 1968). As a rule stomata open in light and close in the dark. Careful experiments have shown that the low internal $\mathrm{CO}_{2}$ level in light, due to photosynthesis, causes stomata to open (Heath \& Milthorpe 1950). A slight opening may also be induced by a direct influence of light (Kuiper 1961). It is supposed that the $\mathrm{CO}_{2}$ and light effects occur only in the guard cells as these are usually the only cells in the epidermis containing chloroplasts. The mechanism by which $\mathrm{CO}_{2}$ concentration influences stomatal aperture is not known and statements about relative influences of water, $\mathrm{CO}_{2}$ and light are essentially estimates. Most of the data in the literature about stomata have been obtained from many different species. Few theories have been formulated dealing with all aspects of stomatal functioning. Those that do exist contain a considerable degree of uncertainty about the relations between various processes and the magnitude the parameters involved (Woo, Stone \& Boersma 1966; Raschke 1970). A more complete model, however, gives a better insight into the transpiration process and acts as a guide for further investigations into plant and crop transpiration.

The model presented here is written in the simulation language Continuous System Modelling Program (IBM 1969), which has proved to be suitable for the programming of 
biological systems (Brouwer \& De Wit 1968; Brennan et al. 1969). Emphasis during model building and testing is nearly always on modelling and not on programming. Perhaps the most important feature of CSMP is its readability, so that the program can also serve for communication purposes. The computer program of the model TRALF has nearly the same order and the same organization as an ordinary written explanation.

The symbolic names used in this paper are similar to the ones used in the listing of the operating computer model which is given at the end of the paper. Each new type of computing statement will be explained briefly in this text.

\section{DESCRIPTION OF THE MODEL AND ITS PROGRAMMING}

First, (section 2.1.1. of the listing) the transpiration rate is calculated from the actual conditions of leaf and environment and the diffusive resistances required are established (2.1.2.). Section 2.2. describes how the stomatal aperture, which is related to the stomatal resistance, depends upon the relative water content of the guard and subsidiary cells (2.2.2. and 2.2.3.2.), the $\mathrm{CO}_{2}$ concentration in the leaf and the light intensity (2.2.3.3.). The $\mathrm{CO}_{2}$ concentration in the leaf is obtained (2.2.3.4.) from the $\mathrm{CO}_{2}$ diffusive resistance, the light intensity and the $\mathrm{CO}_{2}$ concentration outside the leaf. Guard and subsidiary cells relative water content are found from the water balance of the leaf (2.3.1.) and the root (2.3.2.). Finally, the heat balance of the leaf, required for the transpiration computation, is defined (2.4.).

The lines in the listing beginning with an asterisk are not executed by the computer and may contain comments. The last eight places of each line are also not executed and are used for identification.

\subsection{Calculation of transpiration}

\subsubsection{Transpiration rate}

The model is set up to calculate the transpiration rate of a leaf. It starts therefore with a straightforward statement to compute this using an Ohm's law analogy

$$
\text { TRUA }=\text { VCD/TDRES }
$$

which states that the transpiration rate of leaves per unit area (TRUA, $g / \mathrm{cm}^{2} / \mathrm{sec}$ ) is equal to the vapour concentration differential $\left(\mathrm{VCD}, \mathrm{g} / \mathrm{cm}^{3}\right)$ between leaf and surrounding air, divided by the diffusive resistance for water vapour between the leaf and the bulk air (TDRES, sec/cm). The vapour pressure in the leaf is set equal to the saturation vapour concentration (VCLS, $\mathrm{g} / \mathrm{cm}^{3}$ ) at the temperature of the leaf (TL), though this may not be completely true (Jarvis \& Slatyer 1970). TL is derived later in the heat balance section. The tabular relation of temperature to saturation vapour concentration (SVCTB) is given in CSMP by

$$
\text { FUNCTION SVCTB }=(-5 ., 3.41),(-2.5,4.07), \ldots \ldots,(45 ., 65.6) \text {. }
$$

The first term of each pair is the temperature and the second the corresponding saturation vapour concentration $\left(\mathrm{g} / \mathrm{m}^{3}\right)$; in the listing three points following each other indicate that the expression is continued on the next line. This table is read to give the saturation vapour concentration of the leaf at leaf temperature (TL) with the statement

$$
\text { VCLS }=(1 . E-6) * \text { NLFGEN(SVCTB,TL). }
$$

NLFGEN is the name of a function generator which interpolates quadratically between the given points of the table. The factor $10^{-6}\left(1\right.$.E-6) converts $\mathrm{g} / \mathrm{m}^{3}$ to $\mathrm{g} / \mathrm{cm}^{3}$; an asterisk in an expression is the symbol for multiplication. 
The saturation vapour concentration in the air (VCAS) is calculated similarly and then multiplied by the relative humidity to obtain the actual vapour concentration (VCA).

The temperature of the air (TA) is given as a function of time by

$$
\begin{aligned}
& \text { TA }=\text { AFGEN(TATB,TIMIN). } \\
& \text { FUNCTION TATB }=(0 ., 20 .),(1000 ., 20 .) .
\end{aligned}
$$

The AFGEN function generator also enables the introduction of a table (TATB). Again the first term of each pair (here TIMIN) is the independent variable and the second the dependent variable (TA). For the values of time between the ones given in the table the AFGEN function causes a linear interpolation to be performed. In this example TA is constant. The time in some tables is expressed in minutes (TIMIN) and in the rest of the program in seconds (TIME).

The total amount of water transpired by the leaf (TTL, $g$ water), though not an essential element of the model, is found by multiplying the area of the leaf (ARLE, $\mathrm{cm}^{2}$ ) by the integrated value of the transpiration rate per unit area TTUA $\left(\mathrm{g} / \mathrm{cm}^{2}\right)$. The summing in time of TRUA $\left(\mathrm{g} / \mathrm{cm}^{2} / \mathrm{sec}\right)$ is achieved by

$$
\text { TTUA = INTGRL(0.,TRUA). }
$$

The integral function of CSMP (INTGRL) performs the correct integration of the rate presented by the second variable between parenthesis (TRUA); the value of the first name or number represents the level of the integral at the beginning of the simulation. Evidently for this integral the initial value is zero. The integration, performed in a semiparallel fashion, is the realization of the rates over a short time interval (a few seconds) during which they can be assumed to be constant.

\subsubsection{Diffusive resistances}

The total diffusive resistance to water vapour transfer (TDRES, diffusive resistances are expressed in $\mathrm{sec} / \mathrm{cm}$ ) is the sum of the resistance of the air layer adjacent to the leaf (DRESAW) and the resistance of the leaf (DRESL). The boundary layer resistance is calculated using the empirical formula of Monteith (1965) for one single surface, and the diffusion coefficient for water in air.

$$
\begin{aligned}
& \text { DRESAW }=\text { DL/DW; } \\
& \text { DL }=0 \cdot 32 * \text { SQRT(WDTL/WS); } \\
& \text { PARAM WDTL }=10 .
\end{aligned}
$$

DL represents the effective diffusion length $(\mathrm{cm})$. WDTL is the width of the leaf in the downwind direction $(\mathrm{cm})$; the label PARAM (parameter) indicates the type of constant. The windspeed (WS, $\mathrm{cm} / \mathrm{sec}$ ) may vary in time but is here taken to be constant at 10 or 25. SQRT is the name of the function which takes the square root of the expression within parentheses. This formula can be used without correction when the simulated leaf is essentially hypostomatic and all water vapour passes through the lower air layer. The diffusion coefficient of water vapour (DW) is $0.25 \mathrm{~cm}^{2} / \mathrm{sec}$ at $25^{\circ} \mathrm{C}$.

The total resistance of the leaf consists of that of the cuticle (DRESC) and the stomata (DRESS) in parallel. For the cuticle the value of 20 is used, which is common for shade plants (Slatyer 1967, p. 261). DRESS is found from the relation of stomatal conductivity to aperture (FUNCTION CNDSTB) which has been taken from Kuiper (1961) for bean leaves, assuming that the maximal stomatal opening is $8 \mu \mathrm{m}$. The relative stomatal aperture (ARAPER) is calculated later. 


\subsection{Stomatal mechanism}

\subsubsection{Relative stomatal aperture}

Aperture changes in stomata are caused by deformation of the guard cell wall due to change in volume of the guard cells and the adjacent subsidiary cells (Meidner \& Mansfield 1968). It is herein supposed that their effects are additive. The actual relative stomatal

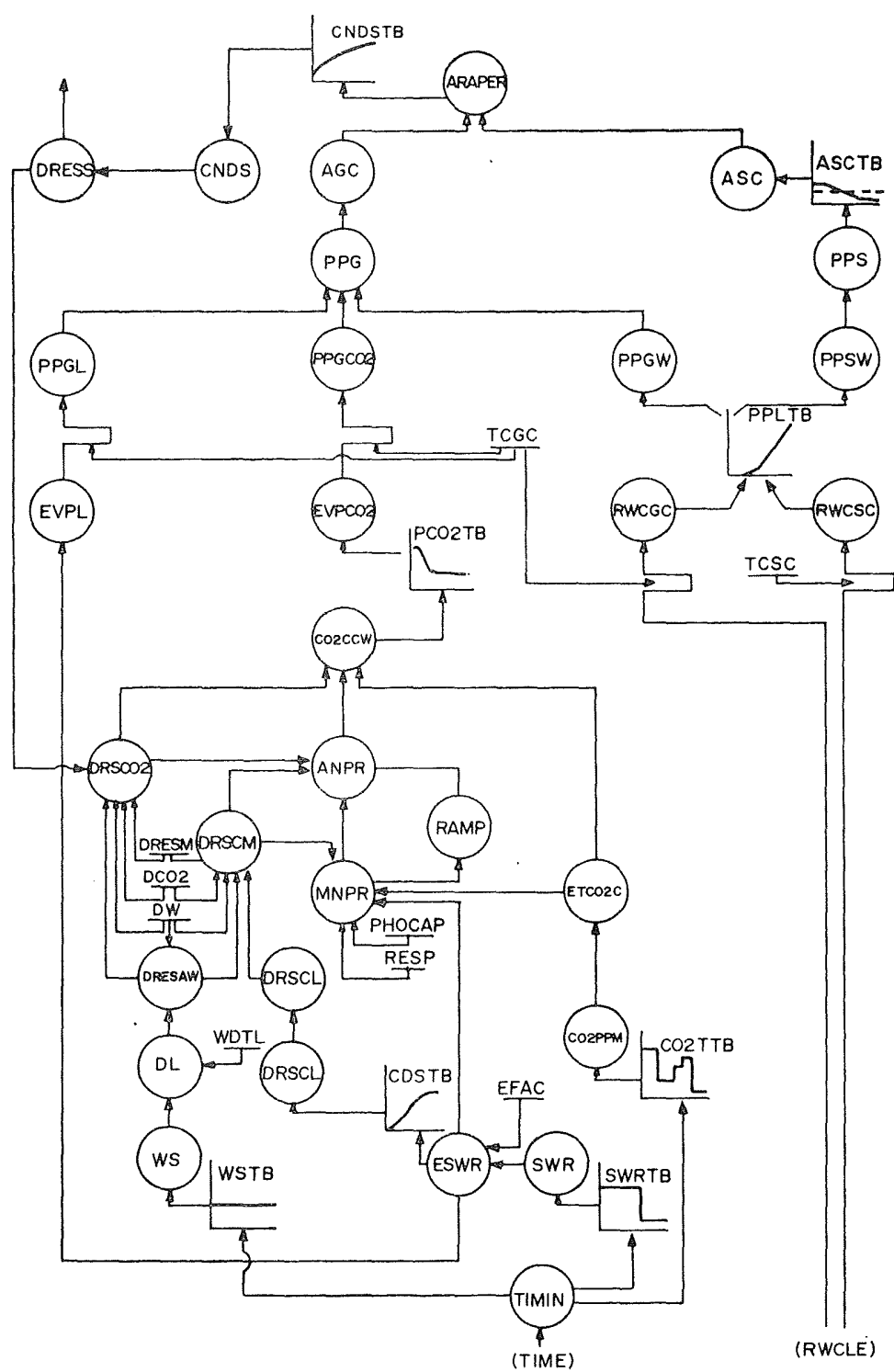

FIG. 1. Relational diagram of the factors contributing to stomatal aperture in the model TRALF. For explanation see text.

aperture (ARAPER, a fraction of its maximum) is found therefore by summing the aperture due to guard cell (AGC) and subsidiary cell (ASC) volume respectively.

$$
\text { ARAPER = AMAX1(0.,AGC+ASC). }
$$

The minimum aperture is 0 ., stated by the AMAX1 function. The change of AGC is 
often called 'active stomatal movement' and change of ASC 'passive movement' (Stålfelt 1955).

Stomata normally close when the leaf water potential falls, in darkness or at a high $\mathrm{CO}_{2}$ concentration in the ambient air. Detailed study of the process of closing induced by darkness showed that the $\mathrm{CO}_{2}$ concentration in the leaf and not light is the mean regulating factor (Heath \& Milthorpe 1950). It is proposed as a working hypothesis that the leaf water potential, $\mathrm{CO}_{2}$ concentration in the leaf and, to a small extent, light directly affect the stomatal aperture, and that their effects are additive.

Fig. 1 is a relational diagram of the stomatal mechanism, which can be used as a guide while reading section 2.2 .

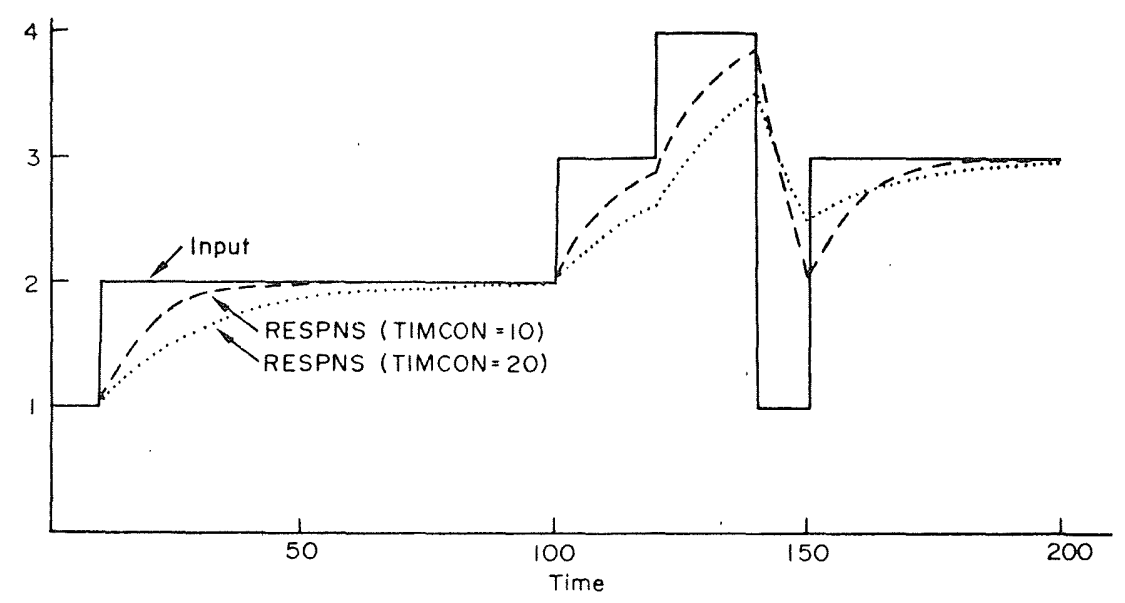

FIG. 2. The response on a stepwise changing input of the CSMP realpole function: FRESPNS = REALPL (1., TIMCON, INPUT). For explanation see text.

\subsubsection{Subsidiary cells}

In most species an increase in water content of subsidiary cells or epidermal cells causes the guard cells to be pressed together, which increases the stomatal resistance (Meidner \& Mansfield 1968). In this model the influence of epidermal cells is included in the subsidiary cell effect. The relative influence of subsidiary cells and guard cells on stomatal aperture is not known. It may be assumed that guard cells are more important in controlling stomatal resistance under steady state conditions as this leads to the most economical use of water for photosynthesis and plant growth. In this model it is rather arbitrarily assumed that the relative stomatal aperture is decreased by the subsidiary cells by 0.2 of its maximum when their pressure potential, or turgor (PPS, bar) is over 10, increases it by 0.2 when PPS is below 2 and is proportional with PPS in between these values (FUNCTION ASCTB). Indications of the order of magnitude of this relationship were found from Meidner (1965) and Raschke \& Kühl (1969), but data of this type are rare.

It is supposed that only the relative water content of the subsidiary cells causes their pressure potential. Evidence for this is based on observations that their pressure potential in light and darkness is near the value of mesophyll cells (Meidner \& Mansfield 1968, p. 21). The relation used between the pressure potential of mesophyll cells and the relative water content of the leaf (FUNCTION PPLTB) is taken from measurements on 
cotton (Gardner \& Ehlig 1965). For subsidiary cells the same relationship is supposed to be valid.

In a steady state the relative water content of the subsidiary cells (RWCSC) is equal to the relative water content of the leaf cells (RWCLE), but when the latter changes, the former follows with a time lag. This time lag was programmed as a first order exponential delay with a time constant of $180 \mathrm{sec}$. In CSMP this was achieved by

$$
\text { RWCSC }=\text { REALPL }(\text { RWCAS,TCSC, RWCLE) }
$$

where REALPL is the function name, RWCAS the initial relative water content of the plant and RWCLE the variable input. Fig. 2 illustrates the response with an exponential delay to an arbitrarily chosen input. In the model the magnitude of the time constant (TCSC) is related to the resistance of the subsidiary cells to water entry from mesophyll cells and was estimated from Raschke \& Kühl (1969). The artificial (i.e. not existing in nature) REALPL construction was used because not enough is known of the process of water entering the subsidiary cells.

\subsubsection{Guard cells}

2.2.3.1. Total pressure potential. The regulating function of guard cells is affected by the relative water content of the leaf, light intensity and the internal $\mathrm{CO}_{2}$ concentration. Light has two different influences; the first is direct and is relatively small, the second is via photosynthesis by lowering the $\mathrm{CO}_{2}$ concentration in the leaf. As a working hypothesis it is assumed that the pressure potential of the guard cells consists of three components, which depend on the relative water content, light intensity, and $\mathrm{CO}_{2}$ concentration respectively.

The sum of the three pressure potentials is the total pressure potential of the guard cells (PPG). It is assumed that, influence of the subsidiary cells apart, the relation stomatal aperture $v$. pressure potential of the guard cells is linear; an experiment of Ursprung \& Blum (1924) gives some support for this. In the guard cells of open stomata the pressure potential (PPG) of a number of species is on average about 21.5 bar and in closed ones about 15 bar, while the pressure potential of mesophyll cells in these plants is about 10 bar (Meidner \& Mansfield 1968, p. 21). If the simulated guard cells are able to open the stomata pore completely at the observed maximum of $21.5 \mathrm{bar}$ and to close it completely at the minimum of $15 \mathrm{bar}$, the relative aperture of the stomata caused by the guard cells (AGC) is given by

$$
\mathrm{AGC}=(\mathrm{PPG}-15 .) / 6 \cdot 5 .
$$

In other words, in this model the effective range of guard cells is 6.5 bar. It is assumed that in guard cells the same relation is valid between relative water content and the fraction of the pressure potential caused by hydration as in mesophyll cells; the excess, from 5 up to 11.5 bar, being due to the internal $\mathrm{CO}_{2}$ concentration and light intensity. In this model the effects of the three separately calculated pressure potentials are additive. Recently Raschke (1970) proposed a quantitatively similar stomatal mechanism.

The mechanism by which the $\mathrm{CO}_{2}$ concentration changes the pressure potential of the guard cells is unknown. Light-activated potassium transport has been demonstrated in guard cells of tobacco plants (Shawney \& Zelitch 1969). Green cells in light produce energy (ATP) at a high rate (Bassham \& Jensen 1967) and it may be that the $\mathrm{K}^{+}$ transport is an active process which requires this energy (Stein 1967) and not light as such. The carbon dioxide effect may then be seen as a direct or indirect stimulation or inhibition of $\mathrm{K}^{+}$transporting enzymes. 
Change in stomatal aperture due to an increase or decrease in relative water content is often called 'hydroactive' and change due to light (and $\mathrm{CO}_{2}$ ) 'photoactive.'

2.2.3.2. Water. The pressure potential of guard cells due to water (PPGW, bar) is found from the function PPLTB using the relative water content of the guard cells (RWCGC) (Fig. 3), this being calculated from the relative water content of the leaf (RWCLE) with an exponential delay. The time constant used (TCGC, seconds) is 1200, being about the average of many observations. Temperature and direction of movement may influence the magnitude of the time constant (Meidner \& Mansfield 1968), but have not been taken into account.

2.2.3.3. Light. From Kuiper (1964) and Mansfield \& Meidner (1966) it can be estimated

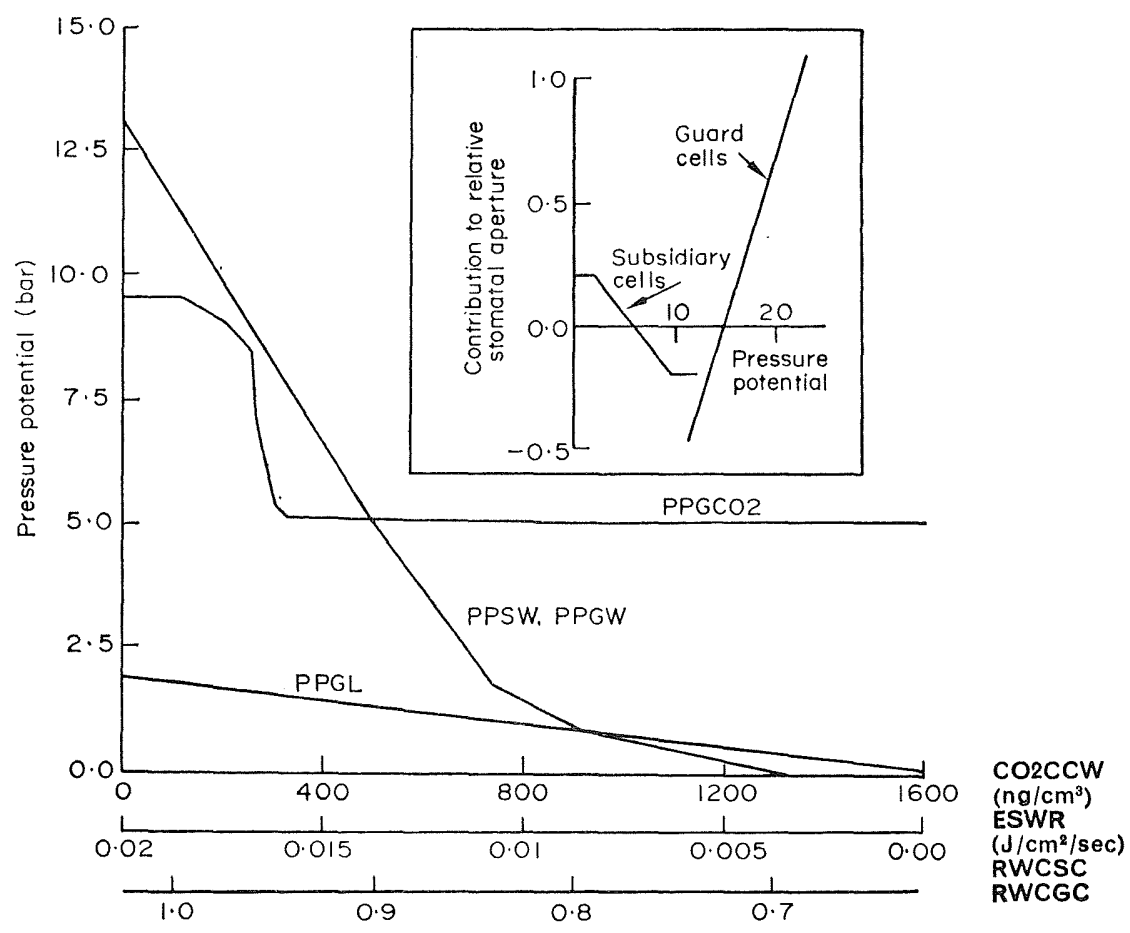

FIG. 3. The assumed relationships between the components of pressure potential in the stomatal apparatus and their causes. The inset represents the relationships between subsidiary and total guard cell pressure potential and the stomatal aperture. For explanation see text.

that the steady state pressure potential due only to light in guard cells (EVPL, bar) is numerically equal to $96\left(\mathrm{bar} \mathrm{cm}^{2} \mathrm{sec} / \mathrm{J}\right.$ ) times the effective light intensity (ESWR, $\mathrm{J} / \mathrm{cm}^{2}$ ) $\mathrm{sec}$ ). This relation was experimentally measured in the range of $0-0.01 \mathrm{~J} / \mathrm{cm}^{2} / \mathrm{sec}$ and may therefore not be valid under field conditions. An exponential delay, similar to the one for PPGW, is used to calculate the actual pressure potential due to light (PPGL, bar).

2.2.3.4. Carbon dioxide. It is assumed that in the steady state a relation (FUNCTION PCO2TB) exists between a $\mathrm{CO}_{2}$ concentration in the leaf $\left(\mathrm{CO} 2 \mathrm{CCW}, 10^{-9} \mathrm{~g} / \mathrm{cm}^{3}\right.$ is $\mathrm{ng} / \mathrm{cm}^{3}$ ) and a fraction of the relative stomatal aperture. $\mathrm{CO} 2 \mathrm{CCW}$ is supposed to be the $\mathrm{CO}_{2}$ concentration at the guard cell walls. A pressure potential (PPGCO2, bar) is taken to be the intermediate between $\mathrm{CO}_{2}$ concentration and a fraction of the aperture (Fig. 3).

The relative rate of change of the leaf $\mathrm{CO}_{2}$ balance is much more rapid than that of

C APP.E. 
water or heat due to the relatively small $\mathrm{CO}_{2}$ storing capacity of a leaf. Thus for the simulation of the transpiration process the internal $\mathrm{CO}_{2}$ concentration at any moment can be considered to be in equilibrium with influx and net photosynthetic rate. To take into account the relatively slow movement of stomata the pressure potential corresponding to this $\mathrm{CO}_{2}$ concentration (EVPCO2, bar) is delayed in a similar manner to PPGW giving PPGCO2 (bar).

The internal $\mathrm{CO}_{2}$ concentration is calculated with a converted flow equation from the external $\mathrm{CO}_{2}$ concentration (ETCO2C), the actual net photosynthetic rate (ANPR, ng/ $\mathrm{cm}^{2} / \mathrm{sec}$ ) and the total diffusive resistance for $\mathrm{CO}_{2}$ (DRSCO2) by

$$
\mathrm{CO} 2 \mathrm{CCW}=\mathrm{ETCO} 2 \mathrm{C}-\mathrm{ANPR} * \mathrm{DRSCO} 2 .
$$

With the line

$$
\text { ANPR }=\text { MNPR } * \text { DRSCM/DRSCO2 }
$$

it is stated that the actual net photosynthetic rate may be given by the product of the maximal net photosynthetic rate (MNPR), which occurs in a steady state when water is not limiting, and the ratio of the diffusive resistance at no water limitation (DRSCM) to the actual resistance (DRSCO2). This implies that no effect of the relative water content on the photosynthetic system has been taken into account. Slavik (1965) showed that there may be an effect of hydration, but it appeared to be small at high relative water contents. DRSCM consists of mesophyll resistance (DRESM), boundary layer resistance and the stomatal resistance as governed by light only (DRSCL), for which Kuiper's (1961) data were used. DRSCO2 is calculated in a similar fashion by replacing the minimum stomatal resistance (DRSCL) by the actual (DRESS). To convert a diffusive resistance for water to a resistance for $\mathrm{CO}_{2}$ it has to be multiplied theoretically by the ratio of the diffusion coefficients for water and $\mathrm{CO}_{2}$, which is 1.73. The mesophyll resistance is assumed to be $3 \mathrm{sec} / \mathrm{cm}$.

The maximal net photosynthetic rate (MNPR, $\mathrm{ng} / \mathrm{cm}^{2} / \mathrm{sec}$ ) is calculated according to formula (5) of Brown (1969), using a constant (PHOCAP, $\mathrm{cm}^{3} / \mathrm{J}$ ), the $\mathrm{CO}_{2}$ concentration in the bulk air $\left(\mathrm{ETCO} 2 \mathrm{C}, \mathrm{ng} / \mathrm{cm}^{3}\right.$ ), the effective radiation (ESWR, $\mathrm{J} / \mathrm{cm}^{2} / \mathrm{sec}$ ), the minimum total diffusive resistance for $\mathrm{CO}_{2}(\mathrm{DRSCM}, \mathrm{sec} / \mathrm{cm})$ and the respiration rate (RESP, $\mathrm{ng} / \mathrm{cm}^{2} / \mathrm{sec}$ ) by

MNPR $=($ PHOCAP*ETCO2C*ESWR-RESP $) /($ PHOCAP*ESWR*DRSCM + 1).

The value 20, used for the constant PHOCAP, is somewhat lower than the average of data collected by Brown (1969). The external $\mathrm{CO}_{2}$ concentration is given in time (FUNCTION CO2TTB) via a table; the concentration in $\mathrm{ng} / \mathrm{cm}^{3}$ is 1.83 times the concentration in ppm. It is assumed that 0.7 (EFAC) of the incident radiation is in the range from 400 to $700 \mathrm{~nm}$ (ESWR). The respiration rate of the leaf is assumed to be $1.7\left(\mathrm{ng} / \mathrm{cm}^{2} / \mathrm{sec}\right)$. Photorespiration and its possible effects, like a post illumination burst of $\mathrm{CO}_{2}$, have not been taken into account. Effects of temperature on the photosynthetic rate are ignored. RAMP is the ratio between the actual net photosynthesis rate and the maximum net photosynthesis rate.

The relationship (FUNCTION PCO2TB) between the pressure potential of the guard cells due to $\mathrm{CO}_{2}(\mathrm{PPGCO} 2)$ and the internal $\mathrm{CO}_{2}$ concentration $(\mathrm{CO} 2 \mathrm{CCW})$ results from the following considerations. In full light without water stress the pressure potential in the actual guard cells is 21.5 bar (see 2.2.3.1.); 10 bar is due to the plant water status, so 11.5 is due to $\mathrm{CO}_{2}$ and light. In darkness the total pressure potential is about 15. bar, of which $10^{\cdot}$ is due to leaf water potential and the remaining $5 \cdot$ to $\mathrm{CO}_{2}$. Using the 
formula of Brown (1969) the internal $\mathrm{CO}_{2}$ concentration was calculated for the experiment of Kuiper (1961, Fig. 14a). The pressure potential of the guard cells in the range of 15-21.5 bar is assumed to be proportional to the stomatal aperture caused by the guard cells (2.2.3.1.). Thus a relation between the internal $\mathrm{CO}_{2}$ concentration and pressure potential due to light and $\mathrm{CO}_{2}$ could be derived. Subtracting the pressure potential caused by light gives the required relationship, presented in Fig. 3.

\subsection{Water balances}

\subsubsection{Leaf}

The relative water content of the leaf (RWCLE) is the actual water content of the leaf (WCLE, $\mathrm{g} / \mathrm{cm}^{2}$ ) divided by the saturated water content (WCLS). To compute RWCLE a water balance of the leaf is maintained by adding the net water gain of the leaf (WGLE, $\mathrm{g} / \mathrm{cm}^{2} / \mathrm{sec}$ ) to the water content of the leaf.

$$
\text { WCLE = INTGRL(WCLI,WGLE). }
$$

The initial value (WCLI, $\mathrm{g} / \mathrm{cm}^{2}$ ) of the water content integral is set equal to the saturated water content (WCLS) times the relative water content at start (RWCAS, fraction). WCLS follows from the thickness of the satured leaf (TCKNSS, estimated at $0.03 \mathrm{~cm}$ ) and the fraction of dry matter in the leaf (FDMLS, estimated at $0 \cdot 1$ ).

WGLE consists of the water supplied by the root (WSUPRT, $\mathrm{g} / \mathrm{sec}$ ) divided by the area of the leaf $\left(\mathrm{ARLE}, \mathrm{cm}^{2}\right)$, minus the transpired water (TRUA, $\mathrm{g} / \mathrm{cm}^{2} / \mathrm{sec}$ ). The rate of water flow from the root towards the leaf is equal to the difference in water potential between them, divided by the resistance of stem and petioles (RESST). No indications of the magnitude of this resistance were found in literature except that it is small compared to the root resistance (Slatyer 1967). The assumption was made that it is equal to one-tenth of the root resistance and this proved to be a reasonable estimate.

The total water potential of the leaf (TWPTLE, bar) is found from the computed relative water content of the leaf using data of Gardner \& Ehlig (1965). This relation is assumed to be valid for leaf and root cells, although experimentally measured for mesophyll cells only.

\subsubsection{Root}

The relative and absolute water content of the root (RWCRT and WCRT, g) are calculated in a similar manner. The flow of water towards the root (WSUPSL, $\mathrm{g} / \mathrm{sec}$ ) equals the difference in total water potential divided by the root resistance (RESRT), taken to be $5 \cdot 10^{5} \mathrm{~cm}^{2}$ bar sec/ $/ \mathrm{cm}^{3}$ (Brouwer 1954), divided by the surface of the root $\left(\right.$ SUFRT, $\mathrm{cm}^{2}$ ). There are indications that the root resistance depends on temperature, metabolic rate and hydration level (Slatyer 1967). The total water potential of the root medium (TWPTSL) was taken to be equal to the osmotic potential (OSPTSL), which was usually set equal to -1 bar.

Root pressure is assumed to be negligible in the simulated plant.

\subsection{Heat balance}

The temperature of the leaf (TL, degrees centigrade) is equal to the heat content of the leaf (HCLE, $\mathrm{J} / \mathrm{cm}^{2}$ ) divided by its heat capacity, which is the product of its thickness and the specific heat of the leaf (SPHL, $4.18 \mathrm{~J} / \mathrm{cm}^{3}$ ). The thickness of the leaf (TCKNS, $\mathrm{cm}$ ) is found from the thickness of the saturated leaf, the relative water content of the leaf and the fraction of dry matter in a saturated leaf. The initial leaf heat content $\left(\mathrm{HCLI}, \mathrm{J} / \mathrm{cm}^{2}\right.$ ) equals the product of the initial thickness of the leaf (TCKNSI), the specific heat of the 
leaf (SPHL) and the initial leaf temperature (TLI), taken to be equal to the air temperature.

The heat balance considers the incoming (ASWR) and outgoing radiation (LWR), sensible (SHL) and evaparative heat loss (EHL) and the fixed or released chemical energy of metabolism (CEIMET). Both CEIMET and LWR are usually less than $10 \%$ of the total energy exchange. All energy fluxes are expressed in $\mathrm{J} / \mathrm{cm}^{2} / \mathrm{sec}(1 \mathrm{~J}=0.2385 \mathrm{cal})$.

The incident short wave radiation (SWR) during simulation is given in table (FUNCTION SWRTB). It is supposed that 0.7 (FRABS) of the incident radiation is absorbed. The net long wave radiation (LWR) is calculated, according to the Stephan-Boltzman law, from emissivities and the difference in absolute temperature of the radiating surfaces and the Stephan-Boltzman constant (SBC, $\left.\mathrm{J} / \mathrm{cm}^{2} / \mathrm{sec} /{ }^{\circ} \mathrm{K}^{4}\right)$.

$$
\mathrm{LWR}=\mathrm{SBC} *(\mathrm{EMISL} *(\mathrm{TL}+273 \cdot) * * 4-\mathrm{EMISW} *(\mathrm{TW}+273 \cdot) * 4) \text {. }
$$

(Two asterisks following each other indicate that the expression before the asterisk is raised to the power behind.) The emissivity for long wave radiation of both leaf (EMISL) and chamber wall (EMISW) is equal to 1. The temperature of the chamber wall (TW) is supposed to be equal to the temperature of the air.

The sensible heat loss (SHL) is the heat flux from the leaf into the air due to conduction. It is proportional to the temperature difference between leaf and surrounding air and inversely proportional to the resistance of the boundary layer to heat transfer (DRESAH, $\mathrm{sec} / \mathrm{cm}$ ). This resistance is found similarly to DRESAW by dividing the diffusion length (DL) by the diffusive coefficient for heat in air (DH), which equals $0.22 \mathrm{~cm} \mathrm{sec}^{-0.5}$. The factor 0.5 is incorporated because the leaf consists of two parallel heat conducting surfaces. A conversion factor $\left(1 \cdot 2 * 10^{-3} \mathrm{~J} / \mathrm{cm}^{3} /{ }^{\circ} \mathrm{C}\right)$ was used to maintain the correct units. The evaporative heat loss (EHL) of the leaf is correlated with the transpiration rate via the latent heat of evaporation of water, which equals $2450 \mathrm{~J} / \mathrm{cm}^{3}$.

The chemical energy involved in plant metabolism (CEIMET) is found from the actual net photosynthesis rate by assuming that each gram of material photosynthesized or respired corresponds with $17500 \mathrm{~J}$.

\subsection{Output and run control}

Because the model was made to see how stomata behave, it has to operate for some simulation time and during this time the values of the variables characterizing the system must be printed. Therefore, besides statements defining the structure of the model, run control statements have to be supplied.

The PRINT instruction states which variables are to be printed in a standard format, as represented in Plate 1(a). The PRTPLOT instruction generates plots of the variables against time; the numbers within parentheses represent the lower and upper limit of the plot following these are variables, which are merely printed (Plate 1b). The DEBUG function is an output facility permitting the printing of all variables of the program with their actual value a number of times $(20)$ after a specified moment $(0 \mathrm{sec})$. The instructions on the card labelled with TIMER indicate the duration of the simulation (FINTIM, seconds) and the time intervals between printing (PRDEL) and plotting (OUTDEL). METHOD MILNE calls the subroutine for integration according to Milne, which proved to be the most suitable of the available integration routines for this model. The RELERR instruction allows the specification of different relative errors for the integrators.

The END card indicates completion of structural, parameter and control definitions for that run of the model. 


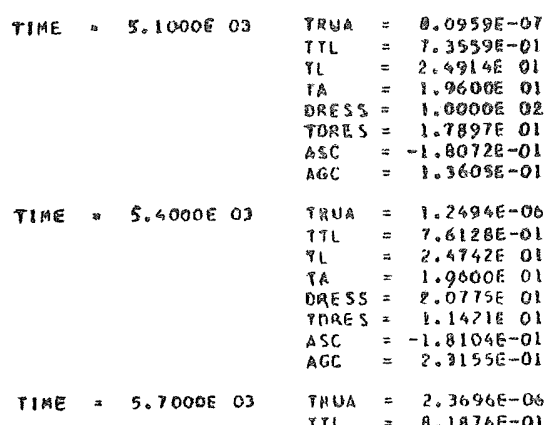

TRUA $=1.2694 E-00$

$T T L=7.6128 E-0 I$
$P L=0.4742 E$ OI

PL $=2.4742 E$ OI

ORESS $=2.0775 E$ OI

PTRES $=2.14218$ OI
ASC $=-1.8104 E-01$
AGC $=2.3155 E-01$

TIAE $=5.7000 E 03$

(b)
ASHR $=1.5560 E-02$

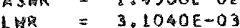

SHL $=9.3061 E-03$

$E M=1.9835 E-03$

CETHEY $=1.0509 E-04$

МคMW

RAAF $=4.2503 E-02$

ASWR $=1.4500 E-02$

NSWR $=1.4560 E-02$
LHR $=3.0005 E-03$

LHR $=3.0005 E-03$
SHL $=9.0626 E-03$

EHE $=3.0610 E-03$

MHPHOY $=3.0555 E 01$

ANER $=3.7895 E O O$

RAMP $=1.0431 E-01$

$\triangle$ SHR $=1.4560 E-02$

$\angle H R=2.2216 E-03$

SHL $=6.7569 \mathrm{E}-03$

CEIHET $=5.8056 E-03$

CEIHET $=1.9365 E-04$

ANPHOT $=2.0555 E$ Ol

RAMP $=5.3836 \mathrm{E}-01$

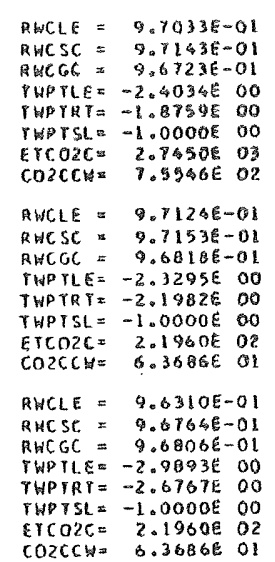

PPL $=9.568$ PE 00

PPS $=9.0144800$

POEH $=9.337200$

PPGL = $1.3776 E 00$

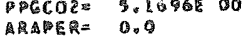

$\begin{array}{ll}\text { ARAPER } & 0.0 \\ \text { TIFIH } & 0.5000 E \text { OI }\end{array}$

PpL $=9.6019600$

DPS $=9.0208 E 00$

$P P G=1.6505 E$ OI

PPGW $=\$ .3998 E 00$

PPGL $=1.3820 E 00$

PPGCOZ= 5.7232E OO

ARAPEA $=3.051 L E-02$

IIAYN 9.0000 OI

PPL $=9.0643 E 00$

PPS $=9.3643 E 00$

PPG $=1.7799 E$ O1

PPGL $=1.3855$ OO

PPGCOZ $7.0010 E 00$

ARADERI 2.5925E-01

YIPIA $=9.5000$ OI

\begin{tabular}{|c|c|c|c|c|c|c|c|c|c|}
\hline & & & VERSUS PIAE & $\begin{array}{c}\text { HAXI MUA } \\
\text { 40 OOODE }-06\end{array}$ & & & & & \\
\hline T IAE & & TRUA & 1 & & $\pi$ & & EHL. & TIAIN & \\
\hline 0.0 & & $4.7213 E-07$ & $\cdots$ & & $1.9600 \mathrm{E}$ & 01 & $1.15078-03$ & 0.0 & \\
\hline $3.0000 \mathrm{E}$ & 02 & $1.5220 E-06$ & $\sim-\infty-\infty-\infty-\infty-\infty-\infty-\infty-\infty-\infty-4$ & & 2.44466 & 01 & $3.72906-03$ & 9.00000 & 00. \\
\hline 6.00008 & 02 & $2.4440 E-06$ & 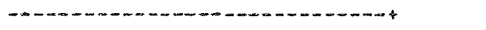 & & 2.31925 & 01 & $3.98936-03$ & 1.00006 & 01 \\
\hline $9.0000 E$ & 02 & $2.7275 E-06$ & 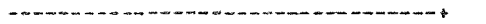 & & $2.2787 \mathrm{E}$ & oi & $6.6825 E-03$ & 1.50005 & ol \\
\hline $1.2000 \mathrm{E}$ & 03 & $2.9192 \varepsilon-06$ & - & & $2.2601 E$ & oi & $P .15198-03$ & $2.0000 \mathrm{E}$ & ai \\
\hline 1.50006 & 03 & $2.4272 \varepsilon-06$ & 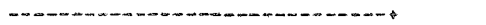 & & $2.2000 E$ & 01 & $5.04565-03$ & $2.5000 E$ & oi \\
\hline 1.8 & 04 & $2.1893 E-06$ & 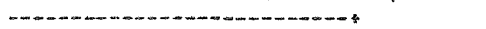 & & $2.2308 E$ & of & $5.3038 E-03$ & $3.0000 \mathrm{E}$ & oi \\
\hline 2. 10008 & 03 & $1.8240 \varepsilon=06$ & 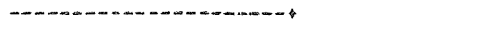 & & $2.2942 \mathrm{KE}$ & 01 & $4.48085-03$ & $3.5000 E$ & 01 \\
\hline $2.4000 E$ & 03 & $1.3743 E-06$ & 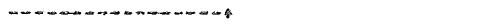 & & $2.3717 E$ & 01 & $3.3671 E-03$ & 4.00005 & 01 \\
\hline $2.8000 E$ & 03 & $9.3768 \varepsilon-07$ & 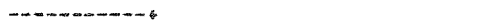 & & $2.4472 \mathrm{E}$ & 01 & $2.29736-03$ & 4.5 & 01 \\
\hline 3.00008 & 03 & $8.05795-07$ & $m-m-\infty-m-\infty-\infty$ & & $2.4801 E$ & 01 & $1.9741 E-03$ & 5. & 01 \\
\hline $3.3000 \mathrm{E}$ & 03 & $8.05005-07$ & 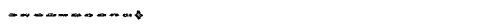 & & 2.48335 & 01 & $1.9744 E-03$ & & 01 \\
\hline 3. $\$ 0008$ & 03 & $8.0837 E-07$ & $-\infty-\infty-\infty \infty+\infty$ & . & $2.3897 E$ & ol & $1.9605 E-03$ & $6.0000 \mathrm{E}$ & 01 \\
\hline $3.9000 \mathrm{E}$ & 03 & $0.0661 E-07$ & $-\infty-\infty-\infty-4$ & & 2.48738 & at & $1.9762 E-03$ & $6.5000 \mathrm{E}$ & 01 \\
\hline $402000 E$ & 03 & $8.0651 E-07$ & $-\infty-\infty-m-\cdots+\infty$ & & $2.4871 E$ & 01 & $1.97396-03$ & $9.0000 \mathrm{E}$ & 01 \\
\hline 4. 5000E & 03 & $0.07105-07$ & $--\infty-\infty-\infty-\infty)$ & & $2.4679 E$ & oi & $1.9774 E-03$ & $7.5000 E$ & \\
\hline 4080005 & 03 & $3,0604 E-07$ & $-\infty \ldots m-\infty-\infty$ & & $2.4873 E$ & oi & $1.8763 E-03$ & $9.0000 \mathrm{E}$ & of \\
\hline 10008 & 0.3 & $0.0959 \varepsilon-07$ & $\cdots-\infty-\infty-\infty-\infty$ & & $2.4914 E$ & oi & $1.9835 E-03$ & & \\
\hline 3.00008 & 03 & $1.2494 E-06$ & 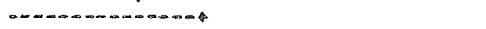 & & 20,7426 & of & $3.0610 \varepsilon-03$ & 9.0000 ê & oi \\
\hline Dooe & 03 & $2.3698 E-06$ & 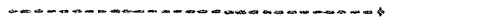 & & $2.3433 E$ & $i$ & $5.8056 E-09$ & $9.5000 E$ & oi \\
\hline & & $8.69602-06$ & $\ldots-\infty$ & & $2.2982 E$ & 01 & $6.6066 \mathrm{E}-03$ & $1.0000 E$ & 02 \\
\hline
\end{tabular}

(a) Example of the standard (SMP PRINT output at times 85,90 and 95 min during simulation of the third experiment of Gaastra. (b) Example of the standard csmP PRTPLOT output at times $0-100 \mathrm{~min}$ during the simulation of the third experiment of Gaastra. 



\subsection{Reruns}

Both a single or a group of new parameter or function definitions between two END cards generate a rerun using the indentical model structure except for the newly defined variable(s). The last (re-)run is characterized by STOP after END.

\section{RESULTS AND DISCUSSION}

With the model described, experiments carried out with turnip were simulated. The transpiration rate, and in one experiment both leaf temperature and net photosynthesis rate, were measured continuously during variations in light intensity and aerial $\mathrm{CO}_{2}$ concentration (Gaastra 1959). Many parameters and functions for turnip had to be

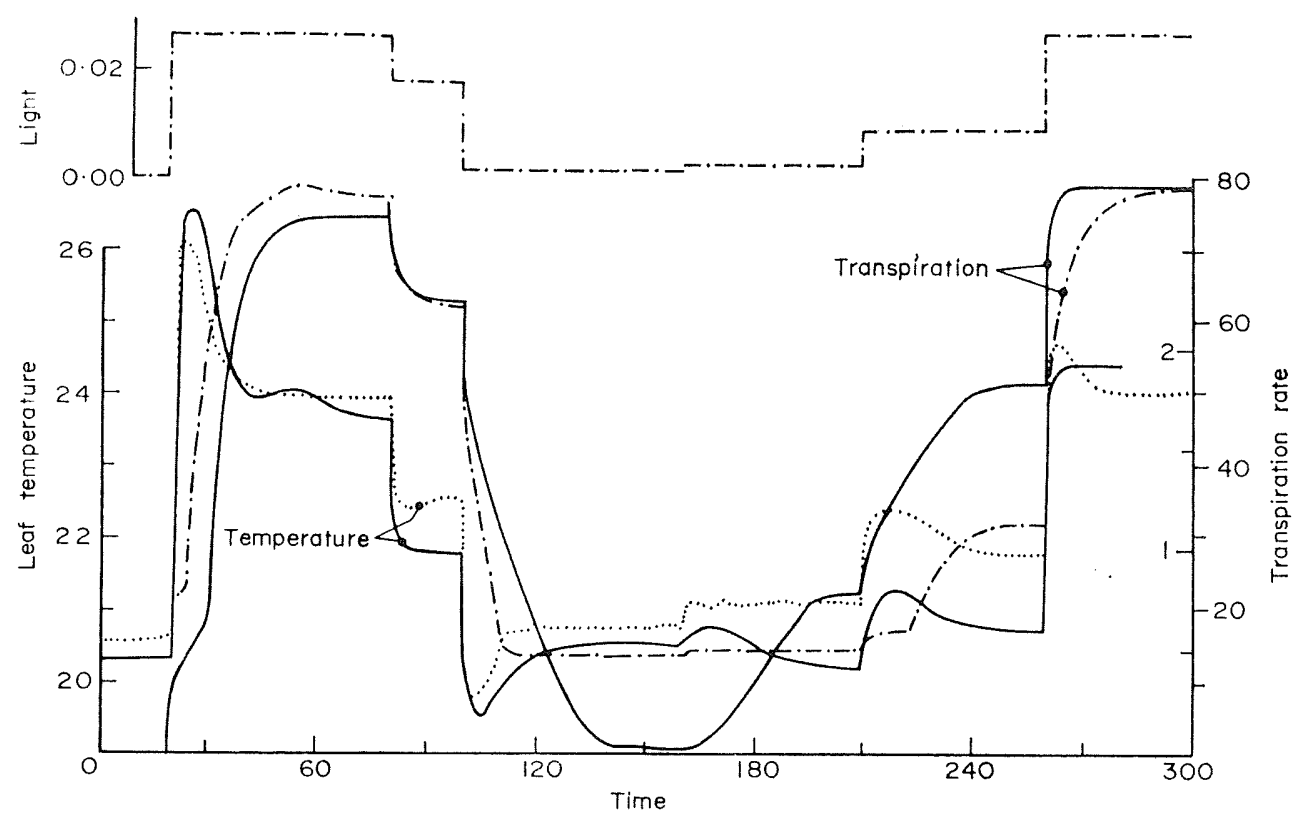

Fig. 4. The measured and simulated (- - ) course of leaf temperature and transpiration rate in time (minutes). The measured rate is relative, the simulated rate is expressed in $\mu \mathrm{g} / \mathrm{cm}^{2} /$ $\mathrm{sec}$ (left on the right scale). The light intensity is given at the top $\left(\mathrm{J} / \mathrm{cm}^{2} / \mathrm{sec}\right)$.

estimated or calculated from other experiments. The author is aware of the limitations of the value of results due to these uncertainties, but it seems the only way at present to test models of this type. Figs. 4-7 were obtained with the listed model. Only functions defining the environment were adjusted to the simulated experiment; no estimations of parameters or functions were made to fit curves.

Fig. 4 illustrates the effect of different light levels on measured and simulated transpiration rate and leaf temperature and Fig. 5 represents the net photosynthesis rate and the internal $\mathrm{CO}_{2}$ concentration. Both experimental rates were relative; for a comparison the simulated and measured maximum were set equal. In these figures there is a good agreement between measured and calculated rates as well in the response to a change in the environment. The main differences are to be seen at low light intensities where the model is the most sensitive to calculations of the internal $\mathrm{CO}_{2}$ concentration used $(\mathrm{CO} 2 \mathrm{CCW})$ to simulate the effect of $\mathrm{CO}_{2}$ concentration on stomatal aperture. About time 


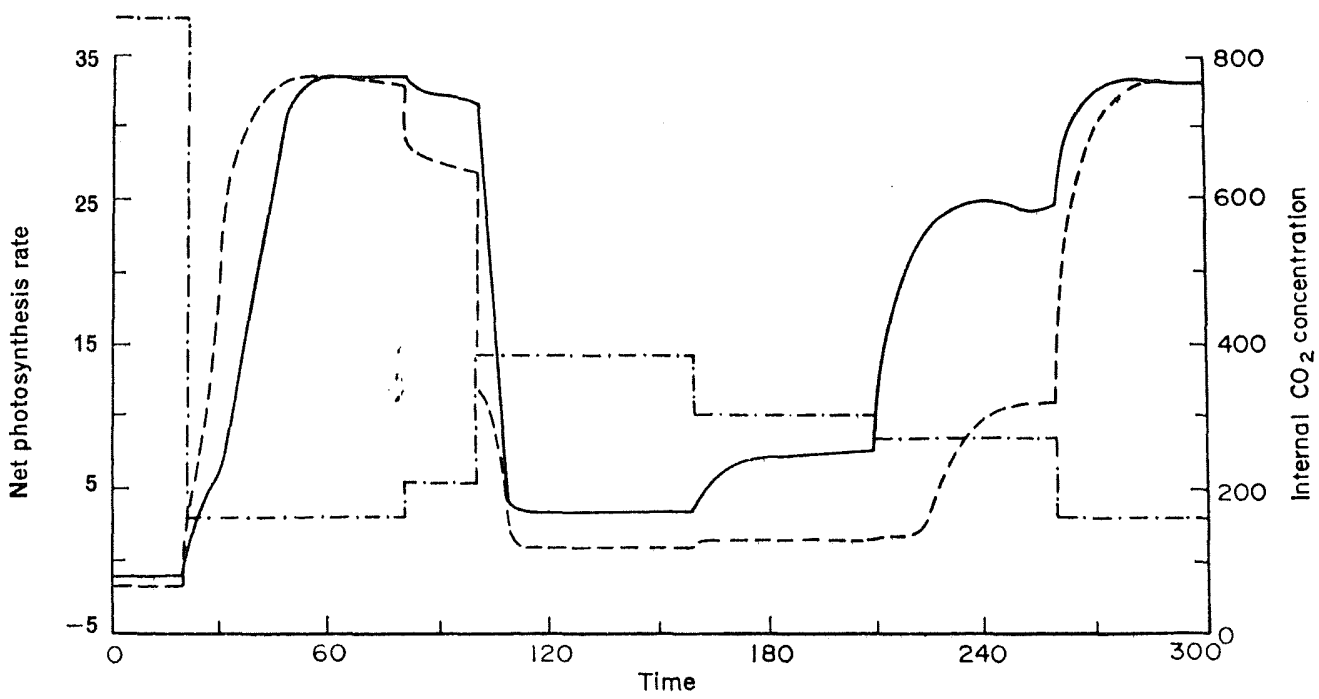

FIg. 5. The measured and calculated (-- ) course of net photosynthesis rate in time (minutes). The measured rate is relative, the simulated rate is expressed in $\mathrm{ng} / \mathrm{cm}^{2} / \mathrm{sec}$. The simulated internal $\mathrm{CO}_{2}$ concentration $\left(\mathrm{ng} / \mathrm{cm}^{3}\right)$ is represented with a dash-dot line.
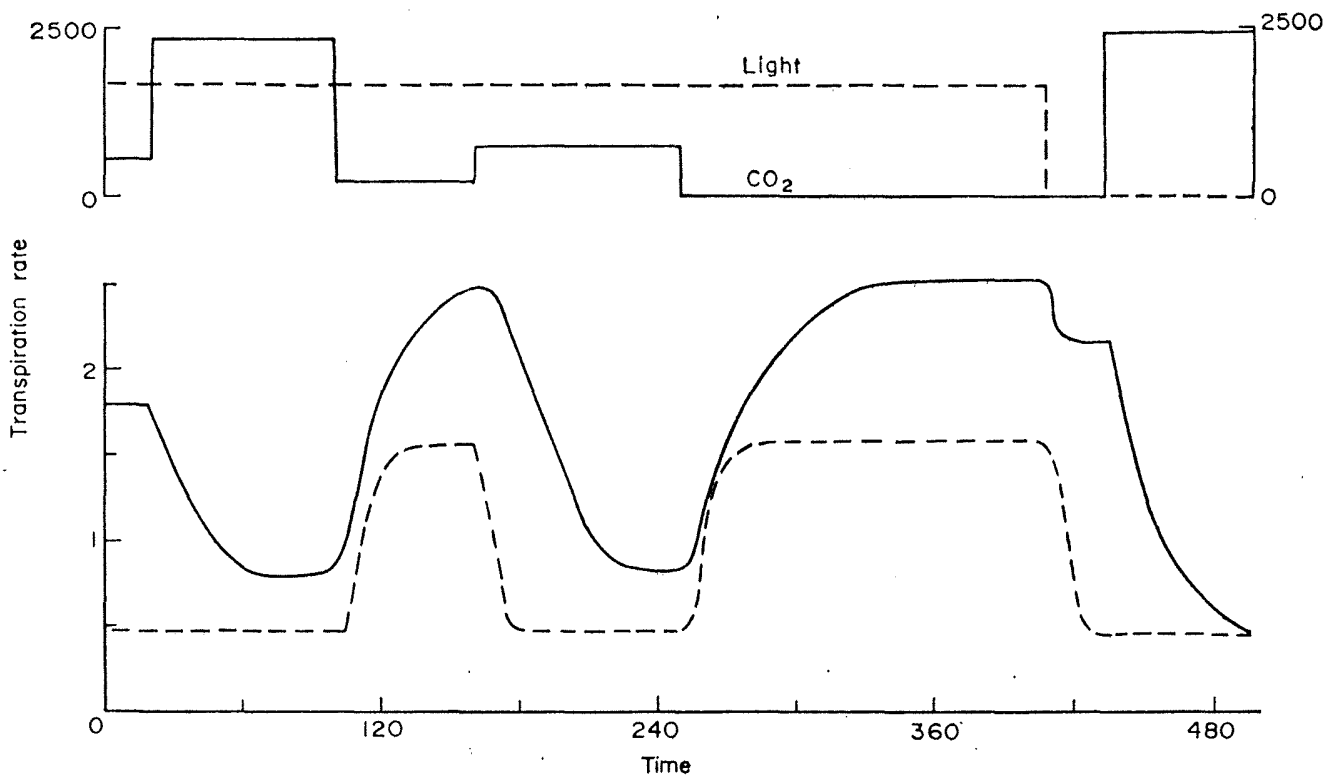

FIG. 6. The measured and calculated (-- ) course of the transpiration rate $\left(\mathrm{ng} / \mathrm{cm}^{2} / \mathrm{sec}\right)$ in the second experiment. At the top are given aerial $\mathrm{CO}_{2}$ concentration $(\mathrm{ng} / \mathrm{cm})$ and incident radiation $\left(\mu \mathrm{J} / \mathrm{cm}^{2} / \mathrm{sec}\right)$. 
150 , there is a disagreement between the experimental value for data about leaf temperature and the measured transpiration rate: the transpiration rate is nearly zero, but the relative leaf temperature is about $-1^{\circ} \mathrm{C}$. This conflict, of course does not occur in the simulation. The slight increase in transpiration rate between 210 and $220 \mathrm{~min}$ is only due to the increase in leaf temperature, the stomata are still closed. After 220 min stomatal opening occurs. The same pattern is to be seen at time 20 , but it is not present in closing movements. The simulated net photosynthesis rate at low light intensities is relatively higher than the experimental rate. This may be due to a different value of the constant (PHOCAP) used in the photosynthesis calculation in the simulated plant and the real turnip.
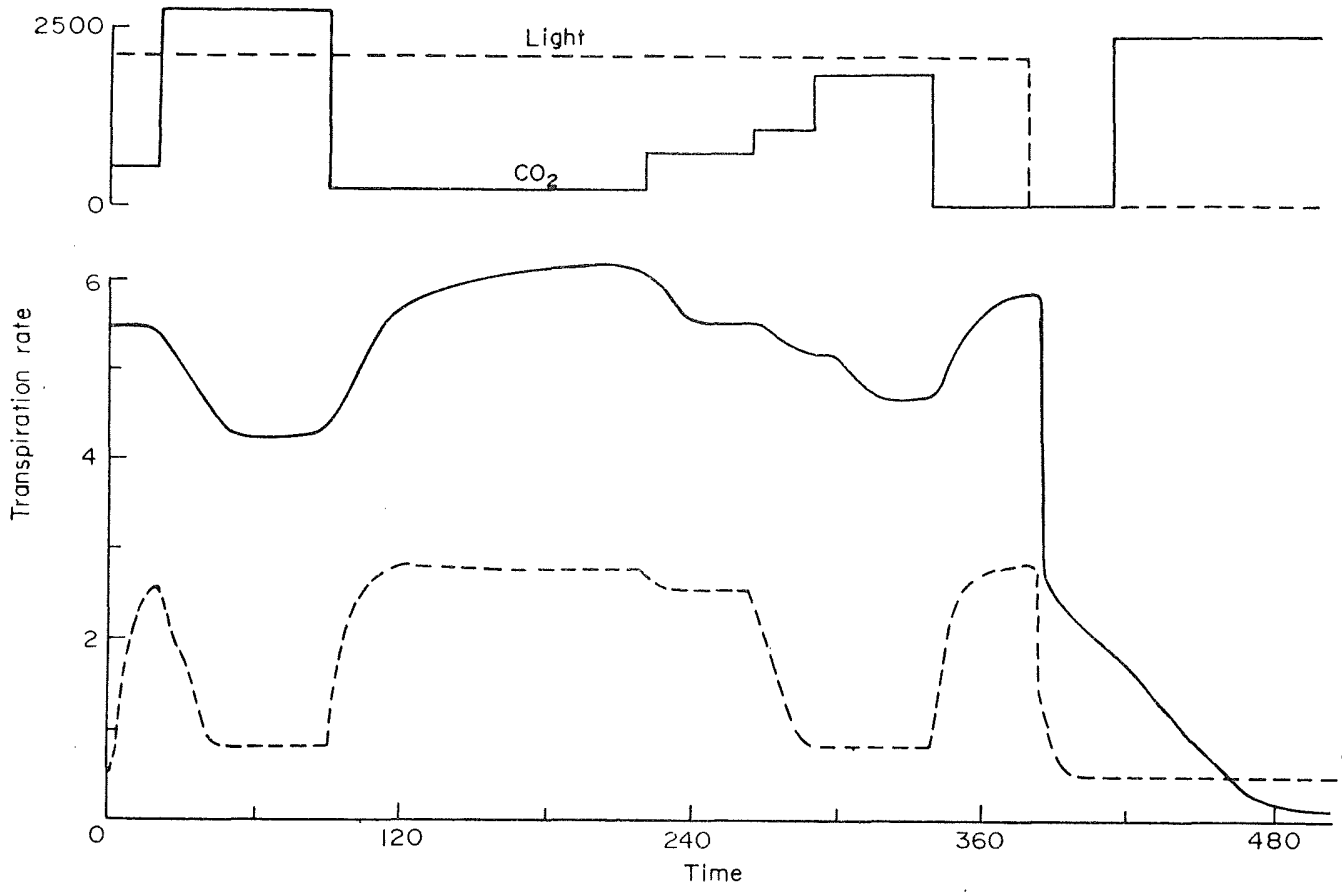

FIG. 7. The measured and calculated (-- ) course of the transpiration rate $\left(\mathrm{ng} / \mathrm{cm}^{2} / \mathrm{sec}\right)$ in the third experiment. At the top are given the aerial $\mathrm{CO}_{2}$ concentration $\left(\mathrm{ng} / \mathrm{cm}^{3}\right)$ and incident radiation $\left(10^{-5} \mathrm{~J} / \mathrm{cm}^{2} / \mathrm{sec}\right)$.

Figs. 6 and 7 illustrate the effect of various aerial $\mathrm{CO}_{2}$ concentrations on the transpiration rate; both measured and simulated rates are absolute. A significant difference exists in the level of the transpiration rate between experiment and simulation when under conditions of a low light intensity and this difference increases at high light intensities. A reason for this difference was not found. Possibly the assumed minimum stomatal resistance was too high. It must be noticed, however, that the experimental relative humidity was not available and only the initial air temperature was measured. The dynamic behaviour of both treatments agrees well, the direction of change in simulation and experiment being always similar but the model responding faster to environmental variations than the plant. When light intensity and aerial $\mathrm{CO}_{2}$ concentration are zero, the model predicts closed stomata, though the real ones still are partly open (Fig. 6) or closing (Fig. 7). The reason for this may be an overestimation of respiration rate and of the relative influence of subsidiary cells on stomatal aperture. 
Simulation of Gaastra's experiments test the model mainly on its response to $\mathrm{CO}_{2}$ and light variations. The behaviour of the simulated stomata and the course of the transpiration rate during water limitations have been tested elsewhere (Lambert \& Penning de Vries 1971), using essentially the same model, coupled to a model of water transport in a cylinder of unsaturated soil (Van Keulen 1971). The results could not be empirically evaluated but did conform to what might be expected. With the combined model longer term dynamics (hours) were investigated. With Gaastra's experiments both short term dynamic (minutes) and static aspects of the model were tested.

The correct way to model biological systems seems to be to describe separately and quantitatively all underlying physiological details together with their structural interrelationships. Often this is not possible because of a lack of knowledge, but it must remain a guiding principle for modelling. In the model described, artificial constructions were introduced in places where the exact interrelationships are not of great importance, as with the simulation of the leaf $\mathrm{CO}_{2}$ balance, or when they are not known. Thus the exact stomatal mechanism is unknown; neither a delay as such, nor a direct conversion from a $\mathrm{CO}_{2}$ concentration to a pressure potential occurs in nature, but they were used to overcome a lack of knowledge. The results of the model agree with the experimental data with an accuracy to be expected, hearing in mind the kind of assumptions that had to be made and the incomplete nature of the experiment with which model behaviour was compared.

The most important parameters and functions about which little is known are: the relative influence of subsidiary and guard cells, the direct effect of light and internal $\mathrm{CO}_{2}$ concentration on guard cells, the constant in the photosynthesis calculation, the diffusive resistance for $\mathrm{CO}_{2}$ in the mesophyll, the resistance to water flow in stem and petioles and the time constant incorporated in the delay functions.

\section{ACKNOWLEDGMENTS}

This work originates from doctoral work done by $\mathrm{H}$. Harssema and the author. I am very much indebted to Professor Dr Ir C. T. de Wit for his critical advice and stimulating interest and to Mr J. N. Gallagher for correcting the English text.

\section{SUMMARY}

A dynamic model of a water-containing and water-conducting system is described, representing a non-growing, transpiring leaf with an attached root in a nutrient solution. The simulated transpiration rate is determined by environmental conditions and leaf conductivity, the latter being mainly under stomatal control. A hypothesis of stomatal functioning based upon the interaction between guard cells and subsidiary cells is presented. The control mechanism of the guard cells is supposed to be affected both by present and past plant water status, light intensity and $\mathrm{CO}_{2}$ concentration in the leaf, which depends on photosynthesis and diffusion rates. The function of subsidiary cells is taken to be affected only by present and past plant water status. Experiments are simulated to evaluate the model.

The model is written in the computer simulation language CSMP and is presented in such a way that the added listing of it may be understood after studying this paper without previous knowledge of programming. 


\section{REFERENCES}

Bassham, J. A. \& Jensen, R. G. (1967). Photosynthesis of carbon compounds. Harvesting the Sun (Ed. by A. San Pietro, F. A. Greer \& T. J. Army), pp. 79-110. Academic Press. London.

Brennan, R. D., De Wit, C. T., Williams, W. A. \& Quatirin, E. V. (1970). The utility of a digital simulation language for ecological modeling. Oecologia, 4, 113-32.

Brouwer, R. (1954). Water adsorption in the roots of Vicia faba at various transpiration strengths. MII. Changes in water conductivity artificially obtained. Proc. K. ned. Akad. Wet. C57, 68-80.

Brouwer, R. \& De Wit, C. T. (1968) A simulation model of plant growth with special attention to root growth and its consequences. Proc. 15th Easter Sch. agric. sci., Univ. Nott. 224-42, Butterworth, London.

Brown, K. W. (1969). A model of the photosynthesizing leaf. Physiologia Pl. 22, 620-37.

Gaastra, P. (1959). Photosynthesis of crop plants as influenced by light, carbon dioxide, temperature and stomatal diffusion resistance. Meded. LandbHoogesch. Wageningen, 59, 13, 1-68.

Gardner, W. R. \& Ehlig, C. F. (1965). Physical aspects of the internal water relations of plant leaves. Pl. Physiol., Lancaster, 40, 705-10.

Heath, O. V. S. \& Milthorpe, F. L. (1950). The role of carbon dioxide in the light response of stomata. II. J. exp. Bot. 1, 227-43.

I.B.M. (1969). System/360 Continuous System Modeling Program (360A-CX-16X), User's manual, H20-0367-03, Tech. Publ. Dep., White Plains, USA.

Jarvis, P. G. \& Slatyer, R. O. (1970). The role of mesophyll cell wall in leaf transpiration. Planta, 90, 303-22.

Keulen, H. van \& Beek, C. G. E. M. van (1971). Water transport in layered soils-a simulation model. Neth. J. agric. Sci. 19, 138-153.

Kuiper, P. J. C. (1961). The effects of environmental factors on the transpiration of leaves, with special reference to stomatal light response. Meded. LandbHoogesch. Wageningen, 61(7), 1-49.

Kuiper, P. J. C. (1964). Dependence upon wavelength of stomatal movement in epidermal tissue of Senecio odoris. Pl. Physiol., Lancaster, 39, 952-5.

Lambert, J. R. L. \& Penning de Vries, F. W. T. (1971). Dynamics of water in the soil-plant-atmosphere system: a model named TROIKA. Symp. Soil-water phys. Technol. Int. Soc. Soil Sci. (In press).

Mansfield, T. A. \& Meidner, H. (1960). Stomatal opening in light of different wavelengths: effects of blue light independent of carbon dioxide concentration. J. exp. Bot. 17, 510-21.

Meidner, H. (1965). Stomatal control of transpirational water loss. Symp. Soc. exp. Biol. 19, 185-204.

Meidner, H. \& Mansfield, T. A. (1968), Physiology of Stomata. McGraw-Hill, London.

Monteith, J. L. (1965). Evaporation and environment. Symp. Soc. exp. Biol. 29, 205-34.

Raschke, K. (1970). Stomatal responses to pressure changes and interruptions in the water supply of detached leaves of Zea mais L. Pl. Physiol., Lancaster, 45, 415-23.

Raschke, K. \& Kühl, U. (1969). Stomatal responses to changes in atmospheric humidity and water supply: experiments with leaf sections of Zea mais in $\mathrm{CO}_{2}$ free air. Planta, 87, 36-48.

Shawney, B. L. \& Zelitch. I. (1969). Direct determination of potassium accumulation in guard cells in relation to stomatal opening. Pl. Physiol., Lancaster, 44, $1350-4$.

Slatyer, R. O. (1967). Plant Water Relationships. Academic Press, London.

Slavik, B. (1965). The influence of decreasing hydration level on photosynthetic rate in the thalli of the heptatic Conocephallum conicum. Water Stress in Plants (Ed. by B. Slavik), pp. 195-202. W. Junk, The Hague.

Stålfelt, M. G. (1955). The stomata as a hydrophotic regulator of the water deficit of the plant. Physiologia Pl. 8, 572-93.

Stein, W. D. (1967). The Movement of Molecules across Cell Membranes. Academic Press, London and New York.

Ursprung, A. \& Blum, G. (1924). Eine Methode zur Messung des Wand- und Turgordruckes der Zell, nebst Anwendungen. Jb. Wiss. Bot. 63, 1.

Woo, K. B., Boersma,'L. \& Stone, L. N. (1966). Dynamic simulation model of the transpiration process. Wat. Resour. Res. 2(1), 85-97.

Woo, K. B., Stone, L. N. \& Boersma, L. (1966). A conceptual model of stomatal control mechanisms. Wat. Resour. Res. 2(1), 71-84.

(Received 29 March 1971) 


\section{LISTING OF THE MODEL}

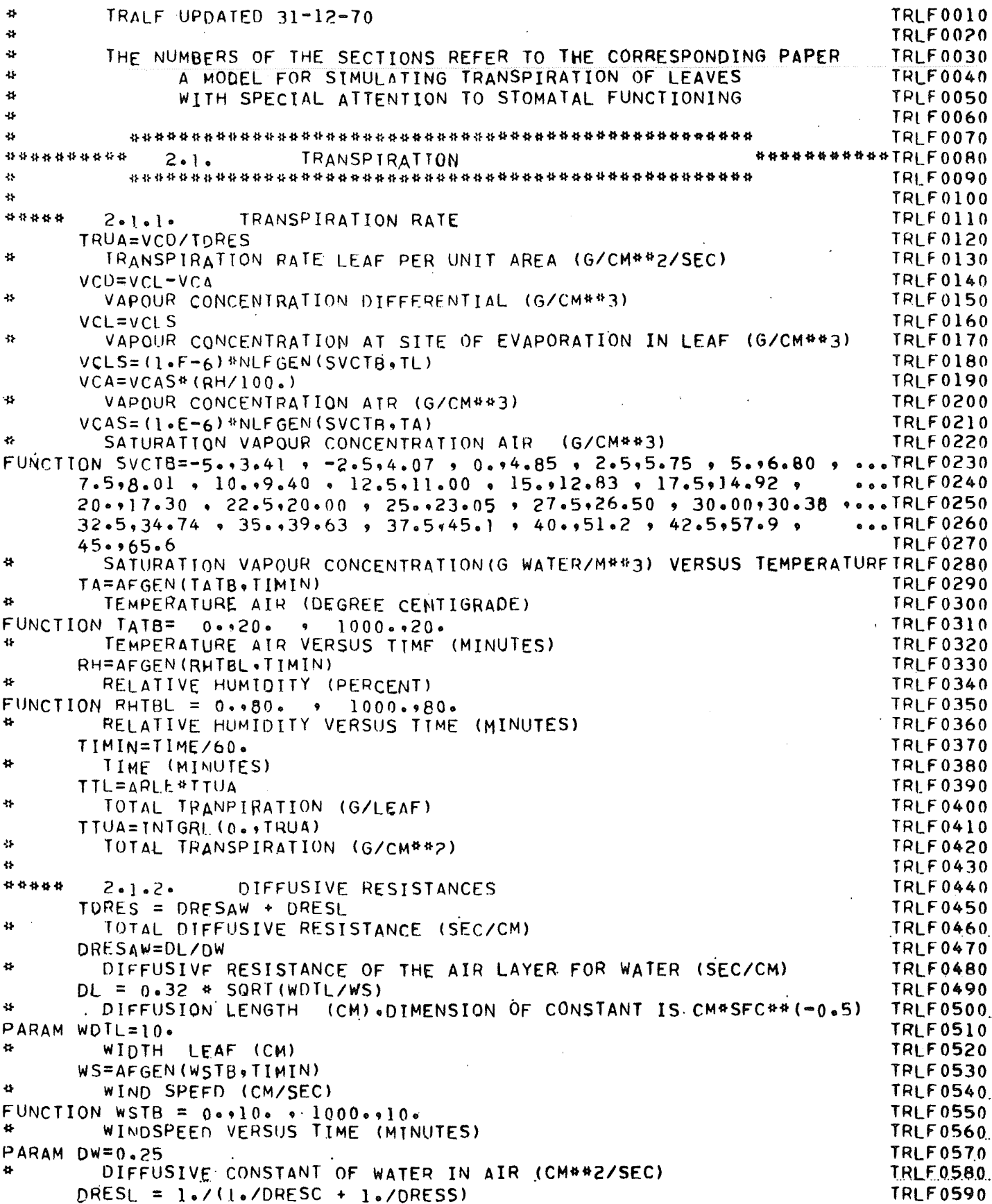


* DIFFUSIVE RESISTANCE LEAF (SEC/CM)

PARAM DRESC $=20$.

* DIFFUSIVE RESISTANCE CUTICLE (SEC/CM)

TRLF 0600

DRESS $=1 . /$ CNDS

* DIFFUSIVE RESISTANCE STOMATA (SEC/CM)

PRLF 0620 CNDS =NLFGEN (C,NLSTB,ARAPER)

36 CONDUCTTVITY STOMATA (CM/SEC)

FUNCTION CNISSTB $=0.00 .01,0.1,0.0855,0.2 .0 .160,0.3,0.212$, $0.4 .10 .250,0.50 .0 .285,0.6 .0 .330,0.7 .0 .365$. $0.8 .0 .390 \cdot 10.0 .390$

CONDUCTIVITY STOMATA VERSUS RELATIVE STOMATAL APERTURE. DATA FROM KUIPER (1961) FOR PHASEOLUS

TRLF 0630

TRLF 0640

TRLF 0650

TRLF 0660

$\therefore$ TRLF0670

TRLF 0690

TRLF 0700

TRLF 0710

TRLF 0720

TRLF 0730

35 .

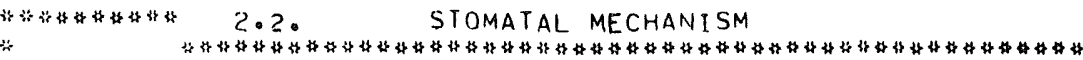

TRLF 0730

$* *$ TRLF 0740
TRLF 0750

TRLF 0760

* 2.2.1 * * RFLATIVE STMMATAI. APFRIURF

ARAPFR =AMAX) $(0 ., A G C+A S C)$

ACTUAL RELATIVE STOMATAL. APERTURE (FRACTION OF MAXIMUM)

TRLF 0770

TRLF 0780

TRLF 0790

\# 2.2.2. SUBSIDIARY CELLS

$A S C=A F G E N(A S C T B, P P S)$

" RELATIVE APERTIIRE OF STOMATA CAIISEN BY SUBSIOIARY CELLS

TRLF 0800

TRLF 0810

TRLF 0820

TRLF 0830

TRLF 0840 CONTRIBIJTION TO RELATIVE STOMATAL APERTURE VERSUS PRESSURE POT. TRLF0850 PDS $=$ OPSW

PRESSURE POTENTIAL SUBSIDIARY CELLS (BAR)

PPSW $=$ AFGEN (PPI. TH, RWCSC)

* PRESSURE POTENTIAL SUBSIDIARY CELLS DUE TO WATER (BAR)

TRLF 0860

TRLF 0870

TRLF 0880

TRLF 0890

$0.90 .4 .9,1.0,11.5,1.1,18$.

PRESSURE PQTENTIAL LEAF TARLE (EXTRAPOLATEI))

VALUES FOR COTTON (GARDNER AND EHLIG 1965.PG 707)

$P P L=A F G E N(P P L T B, R W C L F)$

PRESSURE POTENTIAL IN MESOPHYLL CEILS (BAR)

RWCSC =RFALPL (RWCAS, TCSC,RWCLE)

* RELATIVE WATER CONTENT SIJBSIDIARY CELLS (FRACTION OF MAXIMUM) TRLFO970

PARAM TCSC $=180$

TIME CONSTANT OF FIRST ORDER DELAY, MAGNITUDE INDICATES RESISTANCETRLFO99O

H $2 \cdot 2 \cdot 3 \cdot$ GUARD CELLS

$A G C=(P P G-15 \cdot) / 6.5$

* CONTRIBIJTION TO RELATIVE. STOMATAL APERTURE VERSUS PRESSIJRE POT. TRLFIO3O

2.2.3.1. PRESSURE POTENTIAL GUARD CELLS

$P P G=P P G W+P P G C O 2 \uparrow P P G L$

* PRESSURE POTENTTAL guARO CELLS (BAR)

TRLF 1050

TRLF 1060

TRLF 1061

TRLF 1070

TRLF 1080

2.2.3.2. PRESSURE POTENTIAL DUE TO PLANT WATER STATUS

TRLF 1090

TRLF 1100

PRESSURE POTENTIAL IN GUARD CELLS CAUSED BY WATER (BAR)

TRLF 1110

RWCGC = REALPL (RWCAS, TCGC, RWCLE)

RELATIVE WATER CONTENT GUARD CELLS

TRLFIIIn

PARAM TCGC $=1200$.

TRILF 1.130

* TIME CONSTANT OF FIRST ORDER DELAY, MAGNITUDE INDICATES RESISTANCETRLFIILO

* * 2.2.3.3. PRESSIIRE POTENTIAL DUE TO LIGHT TRLFII60

PPGL $=$ REALPL ( 0 - OTCGC, EVPL)

* PRFSSURE POTENTIAL DUE TO LTGHT (BAR)

TRL.F.1.1.0

TRLF1180 


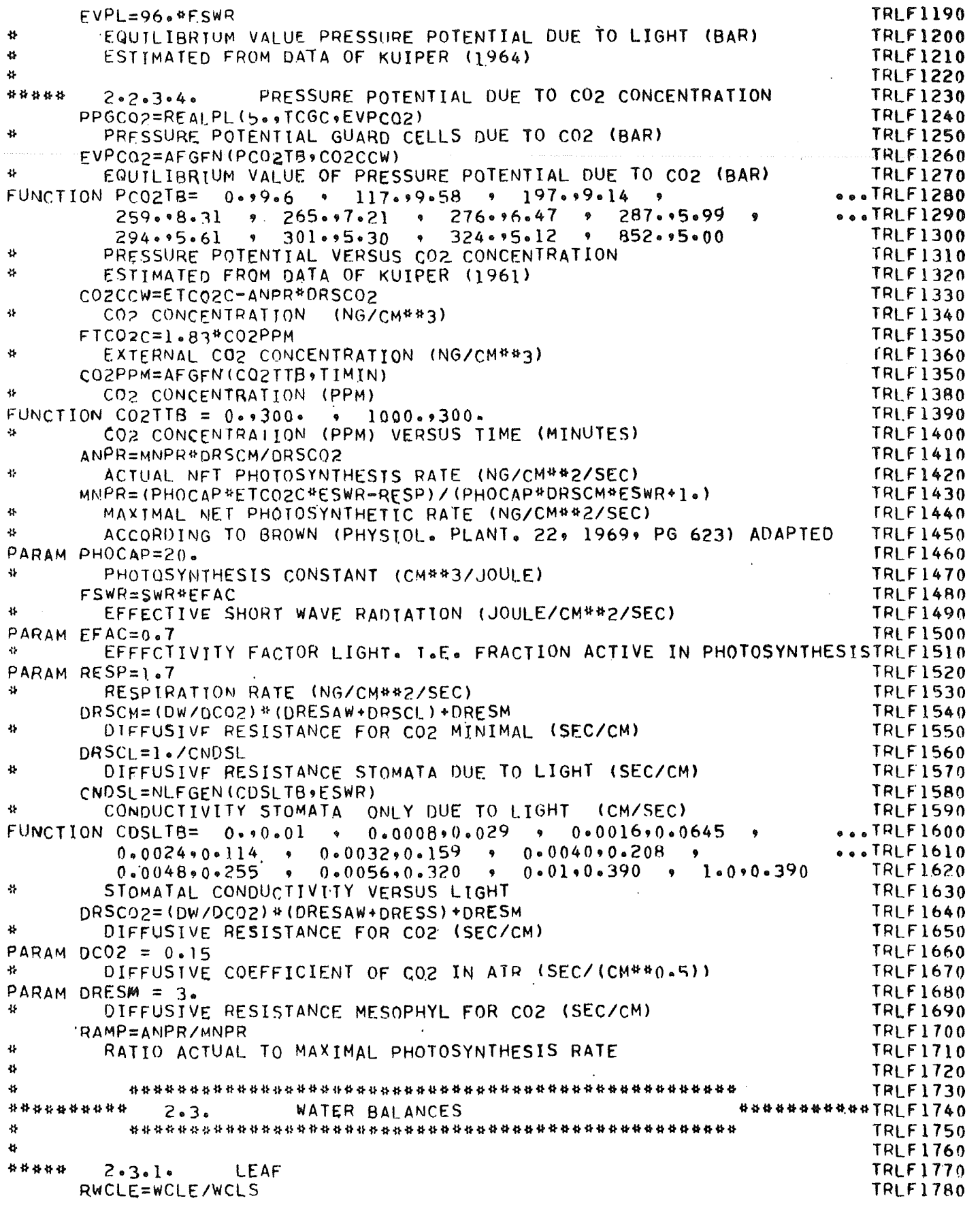


* RELATIVF LEAF water CONTENT (FRACTION OF VALUE at SATURATION) WCLE $=$ INTGRL ( WCLI +WGLE)

WATFR CONTENT LEAF (G/CM*\$?)

WCL $1=W C L S$ \&WCAS

WATER CONTENT LEAF INITIAL (G/CM\#\#2)

WATER CONTE
PARAM RWCAS $=0.98$

* RELATIVE WATER CONTENT AT START

WCLS $=$ TCKNSS * $(1 .-F D M L S)$

अ WATFR CONTENT. LEAF WHEN. SATURATED (G/CM*2)

PARAM TCKNSS $=0.03$

* THICKNESS LEAF WHEN SATURATED (CM)

PARAM FOMLS $=0.10$ FRACTION DRY MATTER LEAF SATURATED

WGLE =WSUPRT/ARLE-TRUA

WATER (IATN LEAF (G/CM\$2/SEC)

WATER IFATN
PARAM ARLE $=100$.

i* AREA LEAF (CH\#2)

WSUPRT = (TWPTRT - TWPTLE) /RESST

WATER SUPPLY TO LEAF FROM RDOT (G/SEC)

* WATER SWPPLY TO LEAF FROM
TWPTLE=AFGEN (TWPLTBQRWCLE)

* TOTAL WATER POTENTIAL LEAF (BAR)

FUNCTION TWPLTB=0.? $0,-60 \cdot, 0.40,-30,, 0.50,-24 \cdot$,

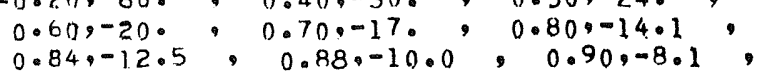
$1 \cdot 00,0 ., 9,1.5,0$. * TOTAL WATER POTENTIAL VERSUS RELATIVE WATER CONTENT
VALUES FOR COTTON (GARDNER AND EHLIG 1965,PG 707 ) RESST $=0.1$ RESRT

RESTSTANCE STEM (SEC/CM)

if

अ** $2 \cdot 3 \cdot 2$. ROOT

WCRT =INTGRL (WC.RI WGRT)

WATER CONTENT ROOT (G)

WATER CONTENT
WCRI =WCRSHRWCAS

WATEK CONTENT ROOT INITIAL (G/ROOT SYSTEM)

WCRS $=V O L R T *(1-F D M R T)$

WATER CONTENT ROOT WHEN SATURATED (G/ROOT SYSTEM)

PARAM VOLRTER

* VOLUME ROOT (CM\#3)

PARAM FOMRT $=0.10$

- FRACTION DRY MATTER IN ROOT SATURATEO WITH WATER

RWCRT $=W C R T / W C R S$

RELATIVE WATER CONTENT ROOT

* RELATIVE WATER CONT

* WATER GAIN ROUT (G/SEC)

WSUPSL $=$ (TWPTSL-TWPTRT) /RESRT

WATER SIIPPIYY TO ROOT FROM ENVIRONMENT. (G/SEC)

TWPTSL $=$ OSPTSI.

TOTAL WATER POTENTIAL SOIL FOR NUTRIENT SOLUTION (BAR)

PARAM OSPTSL $=-1$.

* PARAM OSPTSL $=-1$.

TWPTRT = AF GFN (TWPI. TB, RWCRT)

TOTAL WATER POTENTIAL ROOT (BAR)

RESRT $=1 . /$ (PERRT \$SUFRT)

RESISTANCE ROOT SYSTEM (SEC\#BAR/CM\#\#)

PARAM PERRT $=2$ PE -6

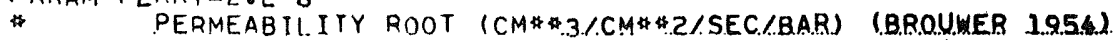

SUFRT $=35$. VOLRT

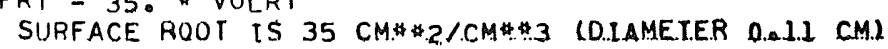

TRLF 1790

TRLF 1800

TRLF 1810

TRLF 1820

TRL.F 1830

TRLF 1840

TRI.F 1850

TRLF 1860

TRLF 1870

TRLF $18 B 0$

TRLF 1890

TRLF 1900

TRLF 1910.

TRLF 1920

TRLF 1930

TRLF 1940

TRLF 1950

TRLF 1960

TRLF 1970

TRLF 1980

TRLF 1990

$\ldots$ TRLF 2000

- TRlfzo10

. TRLF2020

TRLF 2030

TRLF2040

TRLF 2050

TRLF 2060

TRLF 20.7.0

TRLF 2080

TRLF 2090

TRLF 2100

TRLF 21.10

TRLF21?0

TRLF 2130

TRLF 2140

TRLF 2150

TRLF 2160

TRLF 2170 .

TRLF 2180

TRLF2190

TRLF 2200

TRLF 221.0

TRLF 2220

TRLF 2230

TRLF 2240

TRLF 2250

TRLF 2260

TRLF 2270

TRLF 2280

TRLF 2290

TRLF2300

TRLF 231.0

TRLF 2320

TRLF233.0.

TRLF 2340

TRLF. 2350

TRLF 2360

TRLF.237.0

TRLF 2380 


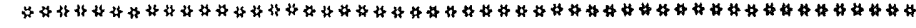

TRLF 2390 Fit स

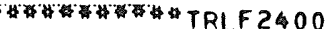

$T L=H C L E$ / (SPHL \&TCKNS)

TFMPERATURE LEAF (DEGREE CENTIGRADE)

CONSTANT SOHL $=4.1855$

SPECIF IC HEAT IEAF (JOULE/CM\#

TCKNS = TCKNSS* (1. -FDMLS) *RWCLE+FDMLS

THICKNESS LEAF (CM)

HCLE = INTGRI. (HCI. I,HGLE)

HEAT CONTENT LEAF (JOLLF/CM\#\#Z)

HCL I = TCKNST \#SPHL iTL I HF. AT CONTENT LEAF INITIAL_ (JOULF/CM\#Z)

$T L I=I A T$

TEMPFRATURE IEAF INITIAL. (DEGREE (ENTIGRADE)

TRLF2410

TRLF2420

TRLF 2430

TRLF 2440

TRLF 2450

TRLF2460

TRLF 2470

TRLF 2480

TRLF 2490

IRLF 2500

TRLF 2510

TRLF 2520

TRLF 2530

TRLF 2540

PARAM TAI $=20$.

TEMPERATURE: ATR INITIAI.

TCKNSI = TCKNSS"( $1,-F D M L S)$ \#RWCAS $+F D M L S)$

THICKNESS LEAF INITIAL (CM)

HGLE = ASWR-LWR-SHL-EHL-CE IMFT

HEAT GAIN LEAF (JOULE/CM\#\#2/SEC)

$A S W R=S W R * F R A B S$

ABSORBED SHDRT WAVE RADIATION (JOULE/CM\# $2 / S E C$ )

TRLF 2550

TRLF 2560

TRLF 2570 .

TRLF2580

TRLF 2590

TRLF 2600

TRLF 2610

TRLF 2620

TRLF 2630

SHORT WAVE RADTATION (JOULF/CM $\# 2 / S E C$ )

1 CAL/CM\#\#2/MIN $=0.0698$ JOULE/CM\#\#2/SEC

FUNCTION SWRTB $=0.00,, 30.90 ., 31.00 .007,60.00 .007$,

$61.0 .014,90.90 .014,91.0 .021,120.0 .021$,

TRLF 2640

TRLF 2650

$121.0 .035,150.00 .035,151.00 .0698,180.00 .0698$ TRLF2680

* SHORT WAVE RADIATION (JOULE/CM\#?/SEC) VERSUS TIME (MINUTES)

TRLF 2680

TRLF 2690

PARAM FRABS $=0.7$

FRACTION ABSORBEO

LWTR $=S B C *(E M I S L *(T L+273) * 440-.E M I S W *(T W+273) * 4$.

TRLF 2700

TRLF 2710

$\begin{array}{lll}\text { 3* LONG WAVE RADIATION (JOULF } / C M \$ 2 / S E C) & \text { TRLF2720 } \\ \text { CONSTANT SRC }=5.673 E-12 \text {. EMISL }=1 . \text { FMISW }=1 . & \text { TRLF2730 }\end{array}$

* STFPHAN BOLTZMAN CONSTANT IN JOULE/CM\$2/SEC/ (DEGREE KELVIN) \#4TRLFZ740 EMTSL AND EMISW ARE EMISSIVITY OF LEAF AND WALL TRLF275n $T W=T A$

TFMPERATURF WAIL. (DFGREE CENTIGRADE)

$S H L=(1.2 E-3)$ * $(T L-T A) /$ TRESAH SENSIBLF. HFAT LOSS JOULF/CM*2/SEC)

DRESAH $=0.5 * D L / D H$

DIFFUSIVE RESISTANCE FOR HEAT OF AIR (SEC/CM)

PARAM DH $=0.22$

DIFFUSIVF CONSTANT FOR HEAT IN AIR (CM\#2/SEC)

TRLF 276 T

TRLF 2770

TRLF 2780

TRLF 2790

TRLF 2810

TRLF 2820

TRLF 2830

TRLF2B4O

TRLF 2850

$F H L=2390.3 T R U A$

EVAPORATIVE HEAT LOSS (JOULE/CM\#2/SEC)

CE IMET $=1 \cdot 75 E-5$ * ANPR

CHEMICAL_ ENERGY INVOLVED IN METABOLISM (JOULE/CM\#2/SEC)

TRLF 2860

TRLF 2870

TRLF 2880

TRLF 2890

TRLF 2900

35

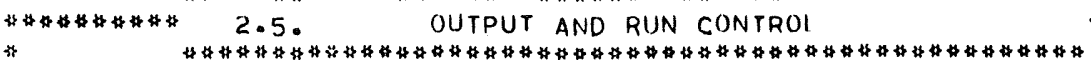

*** TRLF2910

TRLF2920

PRINT TRIIA. ASWR, RWCLE, PPL. D.. TRLF294O

TTL. LWR O RWCSC, PPS,

TL, SHL, RWCGC, PPG. $\because$.

TA. EHL. TWPTLE, PPGW,

DRESS, CEIMET, TWPTRT, PPGL,

TRLF 2950

TRLF 2960

TRLF 297.0

TRLF 2980 


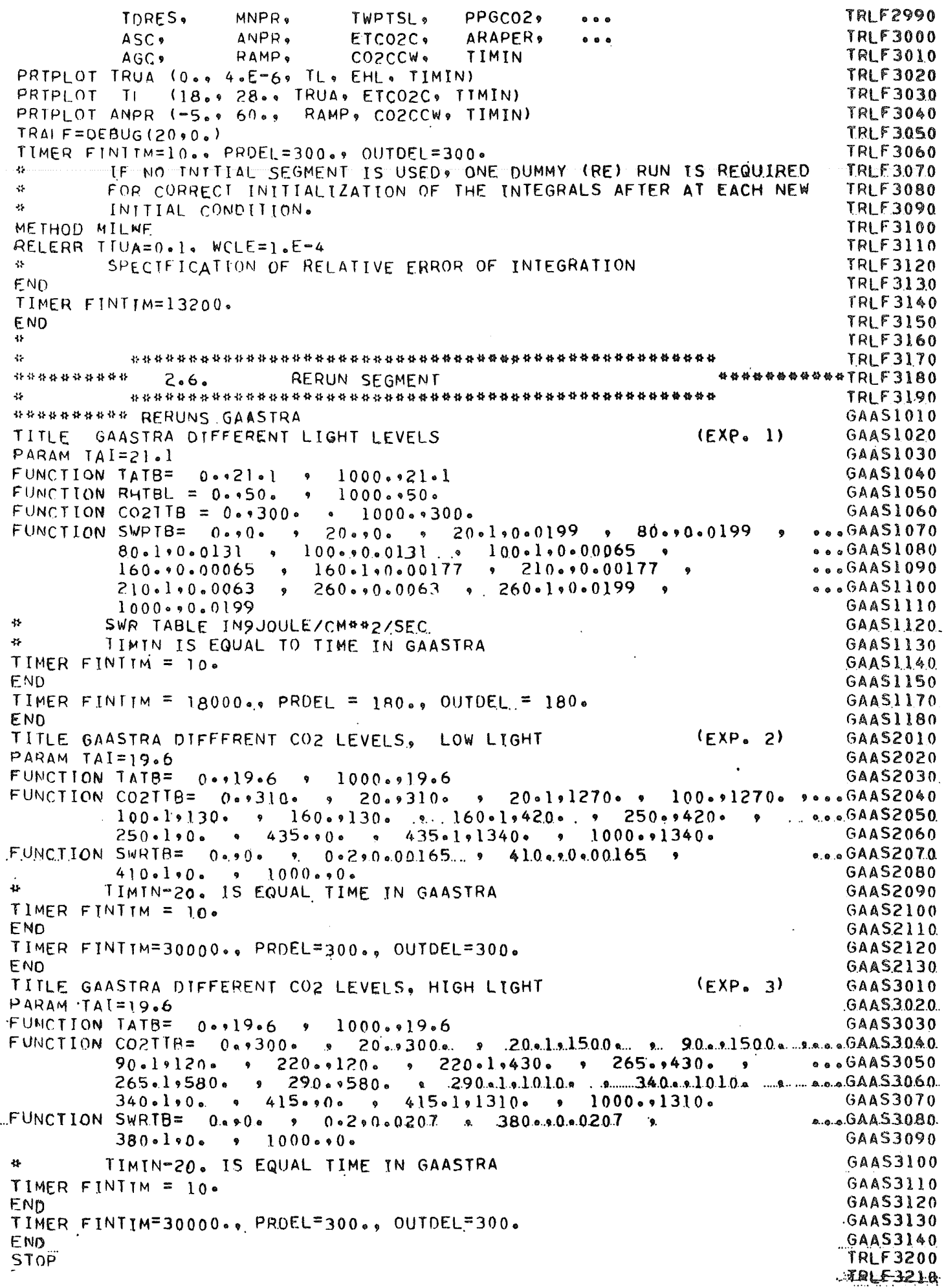


